\title{
To convert or not to convert: the appropriation of Jewish rituals, customs and beliefs by non-Jews
}

\begin{abstract}
In Antiquity, non-Jews appropriated Jewish rituals, customs and beliefs in a way that defied clear-cut categorization and thus challenged group boundaries. Whereas the scholarly debate has traditionally focused on whether the term "Godfearers" (theosebeis, metuentes) was adequate to describe such individuals, and whether such a category or group existed at all in the ancient world, my aim in this paper is different. I examine how ancient literary and epigraphic sources differentiate between converts (or proselytes) and Judaizers, what kind of ritual practices or beliefs are attributed to these Judaizers, and whether they are described as participating in the life of local Jewish communities. Finally, I look at what rabbinic writings have to say about this phenomenon.

Only some of the sources provide information on Judaizing practices; in some cases we can merely conclude that certain non-Jews showed devotion toward the God of Israel, without being able to specify how this devotion manifested itself. It is highly probable that Judaizers were sometimes connected with a particular Jewish community, but not all Judaizers were necessarily taking part in synagogal or community activities. Judaizing attitudes belonged first and foremost to the realm of individual religious practices and were not codified by any particular group. As such, they were rejected by the rabbis, who praised the gentiles who venerated the God of Israel and were benevolent towards the Jews, but considered that the commandments of the Torah such as the Sabbath were given to Israel alone, and were not to be observed or imitated by non-Jews.
\end{abstract}

\section{Introduction}

The scholarly discussion about non-Jews who appropriated Jewish rituals, customs or beliefs without converting to Judaism often refers to these gentiles as

Note: This research has been funded by the European Research Council (ERC) under the European Union's Seventh Framework Program (FP/2007-2013)/ERC Grant Agreement no. 614 424. It has been conducted within the framework of the ERC project JUDAISM AND ROME, under the auspices of the Centre national de la recherche scientifique (CNRS) and AixMarseille University, UMR 7297 TDMAM (Aix-en-Provence, France).

¿ Open Access. ( 2020 Katell Berthelot, published by De Gruyter. (cc) BY-NC-ND This work is licensed under a Creative Commons Attribution-NonCommercial-NoDerivatives 4.0 International License.

https://doi.org/10.1515/9783110557596-024 
"Godfearers" (and sometimes also as "sympathizers"). ${ }^{1}$ The term "Godfearer" has been sharply criticized for its vagueness, and for the fact that the Greek and Latin terms used to designate these people, theosebeis and metuentes, are found in ancient sources in a wide range of contexts, which are not necessarily connected to Judaism. Many inhabitants of the Roman Empire feared the gods and could be labeled accordingly (Feldman 1950; Kraemer 2014). The Jews themselves could be characterized as "fearing God," as being sebomenoi ton theon or yirey shamayim. ${ }^{2}$ Moreover, even when the term is used to refer to Judaizing practices, Ross S. Kraemer is right to recall that "participating in the cultic practices of other groups, while continuing to maintain associations and identifications with one's own group, appears to have been widespread in the Greco-Roman Mediterranean," and should not be seen as a peculiarity of the relationship between Jews and non-Jews (Kraemer 2014, 62). In this paper I shall thus refer to non-Jews who appropriated certain Jewish rituals, customs or beliefs by using the term "Judaizers." 3 However, I shall not restrict my enquiry to the sources which use ioudaizein or iudaizo. Rather, I shall take into account any literary or epigraphic source that documents in one way or another the adoption of Jewish rituals, customs and beliefs by non-Jews.

Insofar as Judaizing attitudes are opposed to conversion, or at least distinguished from it, both in some ancient sources and in modern scholarly literature, we also need to clarify what we mean by "conversion". In the context of ancient Judaism, “conversion” refers to someone's affiliation to the people of Israel, a group that in Jewish, Greek and Roman sources is defined in both ethnic and religious terms. ${ }^{4}$ In Roman sources, for example, the Jews are a gens or a natio, but they are also characterized by their religio. ${ }^{5}$ As we shall see in some of the examples given below, converts are often described as having become Jews. The term "conversion", however, has no precise equivalent in

1 See Lévi 1905-1907; Feldman 1993, 342-382; Lieu 1995; Levinskaya 1996, 51-126; Wander 1998.

2 This leads us to reconsider the evidence from epitaphs, which Pieter van der Horst and others too easily classify as belonging to non-Jews who worshiped the God of Israel, as soon as they see the word theosebēs or metuens. See Van der Horst 1991, 71-72 (in connection with CIJ nos. 5, 202, 285, 500, 524, 529, 619a, 642, 731e, 748, 754 and two inscriptions mentioned by Louis Robert [Robert 1937, 409-412]).

3 As Paula Fredriksen notes, this term has both an emic and an etic dimension. See Fredriksen 2015.

4 On Judaism as an ethno-religion already in the Bible, see Schwartz 2001, versus Cohen 1999. 5 See for example Cicero, Pro Flacco 28.68-69 (religio in §68, gens in §69). 
ancient Hebrew or Greek until Late Antiquity. The Greek term metanoia refers to an inner change and possibly to a change of lifestyle, but not to a change of affiliation. The Hebrew word giyyur ("conversion"), corresponding to the biblical term ger (which, in the biblical books, mostly refers to a stranger living in a permanent way among Israelites), is a late term. ${ }^{6}$ In spite of the relative lack of specific conceptual Hebrew, Greek or Latin terms to refer to conversion to Judaism, the latter is described, especially in Jewish and Roman sources from the end of the 1st century CE onward, as the fact of becoming a Jew, implying the acceptance of all the Jewish (or Mosaic) laws, including circumcision for men. The details of the conversion procedure or ritual, however, elude us to a great extent, and probably varied from place to place, and from one Jewish community to another. It is unclear, for example, how and when the ritual immersion of converts became mandatory in the conversion process. Within rabbinic literature, it is mainly in the Babylonian Talmud (Yebamot 47a-b), the final redaction of which dates to the 6th century $\mathrm{CE}$, that we find information on the conversion procedure; the latter is also described in the tractate Gerim ("Converts"), which is post-Talmudic and thus even later. ${ }^{7}$ As for the term "convert," whereas rabbinic literature uses the biblical word ger(im) with the meaning of "convert(s)", Jewish works in Greek use terms that partly originate from the translation of the occurrences of $\operatorname{ger}(\mathrm{im})$ in the Septuagint, such as prosēlutos (hence the term "proselyte" in English, which in the cases examined in this paper designates converts to Judaism). Among the other Greek terms used in ancient sources to designate converts one may also find epélus / epēlutēs. It must be emphasized that when dealing with conversion and converts to Judaism in Antiquity, we face a case for which we often lack emic technical terms, especially nouns, although the ancient texts describe cases of conversion (using verbs, for example), and provide information on the criteria used to define converts (acceptance of the Jewish laws and circumcision for men, mainly). This case shows that the lack of a term is not tantamount to the absence of a notion; moreover, the fact that a notion is not defined precisely in all its aspects (the conversion procedure, etc.) does not imply that it was not a lively reality in the eyes of the ancient authors.

6 The piel form of the verb gwr, with the meaning "to convert (someone)", "to make a convert", is attested for the first time in the Mekhilta de-Rabbi Ishmael (Amalek [Yithro] 2), a 3rd century CE midrash, and in other 3rd century rabbinic sources.

7 Cohen 1999, chap. 7. 
As Shaye Cohen writes, “Greco-Jewish literature is filled with stories about gentiles, usually kings and dignitaries, who witness some manifestation of the power of the god of the Jews and as a result venerate the god and acknowledge his power" (Cohen 1989, 15-16; see also Cohen 1987). Under the pen of Jewish authors, such stories may stem from a desire to see the superiority of the God of Israel recognized by the gentiles (see for example 2 Maccabees 3:35-36; Judith 5:20-21 and 14:10). In any case, in a polytheistic world, acknowledging the power of a god was always safer than the opposite attitude. To engage in certain practices that were characteristic of the ethnos of the Jews was clearly going one step further, even if we have to keep in mind, following Ross S. Kraemer, that "For many, if indeed not most, persons in antiquity, practice was everything, and it was fluid and variable. Elite officials might strive to set boundaries; ordinary people ignored them" (Kraemer 2014, 84).

Both Judaizing practices and Judaizing beliefs are difficult to define, however. Shaye Cohen has suggested that we should distinguish between seven different stages of "attraction" toward Judaism or adoption of Jewish customs by non-Jews, ranging from mere admiration to full conversion leading to one's integration into a Jewish community as a member of the people of Israel. ${ }^{8}$ Cohen himself grants that it is nevertheless difficult to draw clear-cut boundaries between the different cases he mentions (Cohen 1999, 171). This conclusion is in fact not surprising, as we are dealing with a phenomenon that was to a large extent individual, and to which different groups of Jews reacted in different ways. Some Jewish groups established rules concerning conversion, maybe as early as the Hellenistic period onwards, but the adoption of Jewish rituals, customs or beliefs by non-Jews who did not undergo full conversion eluded control and codification. As we shall see, this attitude could be praised or chastised, but it was hardly ever normalized. But let us first look at the evidence for the existence of such Judaizing attitudes or practices.

8 Cohen 1989, 14-15; Cohen 1999, 140-162. The seven different cases identified by Cohen are: 1) Admiring some aspects of Judaism; 2) Acknowledging the power of the God of the Jews; 3) Benefiting the Jews or being conspicuously friendly to Jews; 4) Practicing some or many of the rituals of the Jews; 5) Venerating the God of the Jews and denying or ignoring all other gods; 6) Joining the Jewish community; 7) Converting to Judaism and "becoming a Jew". 


\section{The appropriation of Jewish rituals, customs and beliefs by non-Jews: a brief review of the evidence}

\subsection{The distinction between Judaizers and converts to Judaism}

The difference between a Judaizer and a convert is reflected in the writings of Josephus, and is also found in Roman authors who were more or less contemporary with Josephus. As far as the Judean historian is concerned, in Judean War 2.454 for example he refers to a Roman officer who had been captured by the Jews at the beginning of the revolt in $66 \mathrm{CE}$, and writes that in order to save his life, the officer promised to Judaize "even to the point of circumcision" (mechri peritomēs ioudaisein). That circumcision was a decisive step equivalent to joining the Judean ethnos is also apparent in the narrative of the conversion of Izates, the king of Adiabene, in Jewish Antiquities 20.34-48.

Interestingly, this distinction is echoed in some Roman sources. The satirist Petronius alludes to the fact that a person would be excluded from the Jewish people if they were not circumcised: "The Jew (Iudaeus) may worship his pig-god and clamor in the ears of high heaven, but unless he also cuts back his foreskin with the knife (ni tamen et ferro succiderit inguinis oram), he shall go forth from the people and emigrate to Greek cities, and shall not tremble at the fasts of Sabbath imposed by the law" (Fragmenta, no. 37, ed. Ernout; trans. M. Heseltine, LCL). The Iudaeus described here could be a native Jew who had not been circumcised at birth, but it makes more sense to identify him as a Judaizer, who will become a member of the Jewish populus only if he agrees to be circumcised. Moreover, as Louis Feldman notes, "Such a passage ... coming from a satirist, has force only if the situation is sufficiently frequent to be recognized by the reader" (Feldman 1993, 346).

Juvenal also testifies to the difference between a Judaizer and a full convert. In a famous passage from the 14th Satire, he writes:

Some happen to have been dealt a father who respects the sabbath (metuentem sabbata patrem). They worship nothing except the clouds and spirit (or: deity) of the sky. They think there is no difference between pork, which their father abstained from, and human flesh. In time, they get rid of their foreskins. And with their habit of despising the laws of Rome, they study, observe, and revere the Judaic code, as handed down by Moses in his mystic scroll, which tells them not to show the way to anyone except a fellow worshipper and if asked, to take only the circumcised to the fountain. But it's the father who is to blame, taking every seventh day as a day of laziness and separate from ordinary life.

(Saturae 14.96-106; trans. S. Morton Braund, LCL, 465-467, slightly modified) 
The Judaizing father is characterized only by the fact that he "reveres the Sabbath" and abstains from eating pork, whereas the son is said to worship heaven (a reference to the identification of the God of the Jews with the heavens, and to the lack of representation of the deity in images), to abstain from eating pork, to undergo circumcision, and to observe the Jewish law, thus becoming a full convert. Moreover, the son is said to have become a stranger to the laws of Rome, to have changed not only religious, but also political and ethnic affiliations. There can be no doubt that, at least from the end of the 1st century CE onwards, Roman authors understood conversion to Judaism as being tantamount to a very real change of identity, and did not consider it equivalent to Judaizing practices.

Finally, the Stoic philosopher Epictetus also indirectly alludes to the difference between Judaizers and converts when he calls out to a man asking "why do you act the part of a Jew, when you are a Greek?" and makes the following observation: “ ... whenever we see a man halting between two faiths, we are in the habit of saying, 'He is not a Jew, he is only acting the part.' But when he adopts the attitude of mind of the man who has been baptized and has made his choice, then he both is a Jew in fact and also is called one" (Arrian, Diss. 2.9.20; trans. W. A. Oldfather, LCL, 267). Epictetus mentions baptism (immersion in a ritual bath) as the main rite for conversion, rather than circumcision, which applied only to men. This observation is in fact one of the earliest nonJewish testimonies that we have for the immersion of converts. ${ }^{9}$ The main point here, however, is the distinction Epictetus draws between a convert, who has become a Jew, and one who is only "acting the part". Moreover, the implication of Epictetus' general remark is that such Judaizers were numerous. But what did Judaizing practices consist of?

\subsection{What did Judaizing practices consist of?}

Josephus writes in his polemical treatise Against Apion (Ag. Ap.):

What is more, even among the masses for a long time there has been much emulation of our piety (eusebeia), and there is not one city of the Greeks, nor a single barbarian nation, where the custom of the seventh day, on which we rest, has not permeated, and where

9 Tosefta Avodah Zarah 3:11 mentions circumcision followed by ritual immersion as a requirement for a male non-Jewish slave who was bought by Jews. However, the slave was considered a Jew only after having been manumitted. In the case of a female slave, only immersion was required, and she would also be considered Jewish only after manumission. See Hezser 2005, 35-38. 
our fasts (nēsteiai) and lighting of lamps (kai luchnōn anakauseis) and many of our prohibitions with regard to food (kai polla tōn eis brōsin hēmin) have not been observed.

(Ag. Ap. 2.282; trans. Barclay 2007, 327-328) ${ }^{10}$

That Josephus is not talking here about conversions is made clear by another passage of Against Apion in which he defines converts as those who become members of the politeia of the Jews, using a political metaphor already found in previous Jewish texts written in Greek. What he describes in Ag. Ap. 2.282 can thus be characterized as Judaizing practices. ${ }^{11}$ Whether these Judaizers were connected to a Jewish community in one way or another remains unclear. I shall come back to this point later.

It seems that numerous non-Jews did in fact observe the Sabbath in one way or another. ${ }^{12}$ In fact, the lighting of lamps, which Josephus states was a Jewish practice imitated by non-Jews, is associated by Seneca with the Sabbath (Epistulae 95.47), and by Persius with "Herod's day," probably to be identified with the Sabbath as well (Saturae 5.180-181). ${ }^{13}$ Hence it is in all likelihood a reference to the custom of lighting lamps before the Sabbath began at sunset. In connection with the story of the translation of the Law of Moses into Greek, Philo writes that the Jewish laws "attract and win the attention of all, of barbarians, of Greeks, of dwellers on the mainland and islands, of nations of the east and the west, of Europe and Asia, of the whole inhabited world from end to end," and he adds: "For, who has not shown his high respect for that sacred seventh day, by giving rest and relaxation from labour to himself and his neighbours, freemen and slaves alike, and beyond these to his beasts?" (De Vita

10 See also Josephus, Judean (or Jewish) War (J.W.) 2.463, 560; 7.45 (on which see below). Josephus also refers to specific individuals who adopted Jewish customs, without describing them as having become Jews. See for instance Jewish Antiquities (Ant.) 18.8 (concerning a Roman matrona called Fulvia), and the analysis of Daniel R. Schwartz (Schwartz 2007, esp. 96).

11 Similarly Barclay 2007, 328: "Josephus is here describing the imitation of particular customs, not the wholesale adoption of the Judean law."

12 See Goldenberg 1979. In addition to the sources quoted below, one could mention a passage from Suetonius (Tiberius 32.2) referring to the grammarian Diogenes, who, at the beginning of the 1st century, used to lecture every Sabbath in Rhodes and who refused to come and lecture in front of the emperor Tiberius on any other day. When this same Diogenes came to Rome and wished to pay his respects to Tiberius, the latter responded that he'd better come back in the seventh year - probably an ironic allusion to the Sabbatical year. This reference to the practice of lecturing exclusively on the Sabbath is surprising. It has been interpreted by Louis Feldman as meaning that Diogenes was a Sabbath-observer (Feldman 1993, 345). The question that arises is: what kind of lecture would be given only on a Sabbath? Another question pertains to the identity of Diogenes, who may have been a Judaizer, but also a Jew.

13 For the opposite opinion, that Persius is alluding to a celebration connected to Herod, see Horbury 1991. 
Mosis 2.20-21, trans. F. H. Colson, LCL, 459-461). Philo suggests that the Sabbath is observed universally, which sounds like wishful thinking, but could also be understood as an exaggerated way of expressing the same idea found in Against Apion. In \$2.23-24, Philo also refers to the admiration expressed by non-Jews for the fast of the Day of Atonement (Kippur). In fact, it is probable that Josephus partly drew his inspiration from Philo, even if the descriptions of the former sound a bit more realistic than those of the latter.

That Philo's and Josephus' statements are not totally far-fetched may be deduced from a fragment of Seneca's De superstitione quoted by Augustine in De Civitate Dei 6.11:

Along with other superstitions of the civil theology Seneca also censures the sacred institutions of the Jews, especially the sabbath. He declares that their practice is inexpedient, because by introducing one day of rest in every seven they lose in idleness almost a seventh of their life, and by failing to act in times of urgency they often suffer loss. But when speaking of the Jews he says: 'Meanwhile the customs of this accursed race have gained such influence that they are now received throughout all the world. The vanquished have given laws to their victors.' ～(trans. W. M. Green, LCL, quoted in Stern 1974-1984, 1:431)

If Augustine's testimony is reliable, this quotation reflects the fact that numerous non-Jews had adopted Jewish customs and rites, although it remains unclear whether Seneca referred to Judaizers or full converts, or both. This distinction was probably irrelevant to him. Beyond the reference to the spread of Jewish customs, it is interesting that Seneca refers to Judaizers in connection with his criticism of the sabbatical rest.

Apart from the texts quoted so far, the best evidence we have for some kind of observance of the Sabbath by non-Jews who were not converts comes from the works of 1st and 2nd century Roman poets and satirists. These works are grounded in contemporary social realities, to which they refer only in passing, sometimes quite obscurely. I have already mentioned Petronius' remark on "the fasts of Sabbath imposed by the law." Tibullus is less clear; he writes that "Either birds or words of evil omen were my pretexts, or there was the accursed day of Saturn to detain me" (Elegiae 1.3.17-18; trans. J. P. Postgate, LCL, 207). According to most scholars, he is referring to the Jewish Sabbath. ${ }^{14}$ Tibullus' words are not to be taken literally, however, but are rather an indication that it was conceivable for a Roman to observe or revere the Sabbath. In Sermones 1.9.60-78, Horace features a certain Aristius Fuscus who claims that, because of the Sabbath, he cannot deal

14 See for instance Reinach 1894, 247; Stern 1974-1984, 1:319-320. On the association between the Sabbath and the "day of Saturn," see also Tacitus, Hist. 5.4.4; Frontinus, Strat. 2.1.17; Cassius Dio 37.16-19; Tertullian, Nat. 1.13; Barclay 2007, 328. 
with certain issues. The passage is difficult to interpret, but implies that Aristius Fuscus somehow observed the Sabbath of the Jews. Moreover, he presents himself as a superstitious man, which seems to imply that, in Horace's perspective, this Jewish custom was a superstition. A famous passage from Persius' fifth satire refers to the "day of Herod," which as mentioned above probably refers to the Sabbath, and contains a vivid description of it:

But when the days of Herod come, and the lamps, wearing violets and arranged along the greasy window, spew out a fatty fog, when the tail of tuna fish swims coiling round the red bowl, when the white pitcher is bulging with wine, you silently move your lips and turn pale at the circumcised sabbath.

(Saturae 5.179-184; trans. S. Morton Braund, LCL, 111-112, slightly modified)

The person Persius is addressing is clearly not a Jew himself, but rather a Roman who is presented as participating in the Jewish celebration. Here the Sabbath is associated with circumcision, a characteristic of the Jews in Persius' eyes. The meaning of "you silently move your lips" is unclear, and could be an allusion to the prayers that the Judaizing Roman is taking part in. Finally, as mentioned previously, Juvenal's 14th Satire refers to a man who rests on the Sabbath and whose son, as a result, becomes a full convert, but he does not give details on the practice itself (see §2.1 above).

Roman authors often associated the sabbatical rest with fasting. ${ }^{15}$ Based on the testimony of these Roman authors, Margaret Williams has suggested that Jews in Rome did in fact fast on the Sabbath, arguing that the Sabbath was associated with the capture of Jerusalem by Pompey in 63 BCE and by Sosius in 37 BCE, and thus with the subsequent exile of Judeans to Rome. ${ }^{16}$ In Against Apion, Josephus refers to the ritual of Jewish "fasts," but he probably implies first and foremost the Day of Atonement, as Philo does in De Vita Mosis. It is unclear what Jewish practice was being imitated by the non-Jews who are described as engaged in a "Jewish fast". Moreover, it is possible that Jews like Josephus interpreted other people's fasts as an imitation of their own, but that this interpretation was mistaken.

In any case, some testimonies, like that of Juvenal, unmistakably refer to nonJews who revered and observed the Jewish day of rest. What eludes us are the

15 On the association of the Sabbath with fasting, see Pompeius Trogus, apud Justin, Epitome 36.2.14; Petronius, Fragmenta, no. 37 (he speaks about "the fasts of Sabbath [ieiuna sabbata] imposed by the law"); Martial, Epig. 4.4.7; Suetonius, Life of Augustus 76.2. See Goldenberg 1979, 439 (he suggests that the association could stem from the fact that the Jews refused to light fires and cook on the Sabbath).

16 See Williams 2004. Goldenberg cautiously considers it a possibility, but leaves the question open (Goldenberg 1979, 439-441). 
details of this practice and the connection these Judaizers may or may not have established with Jewish communities.

\section{Judaizers and Jewish communities}

A striking feature of the Greco-Roman sources mentioned previously is that they often refer to individuals. Horace mentions a Judaizer by name (Aristius Fuscus), Persius and Epictetus address an anonymous individual, Juvenal mentions the case of a father and his son, Josephus tells the story of individuals attracted to Judaism or sympathetic to the Jewish cult. ${ }^{17}$ Judaizing attitudes are thus generally presented as individual phenomena, even if Philo and Josephus boast of the numbers of non-Jews imitating Jewish customs, and occasionally make generalizing statements concerning the population of a city or even humankind as a whole.

We do not know many details concerning the religious practice of the Judaizers, however. In particular, we may ask the question whether these people observed the Sabbath (or other rituals) individually or in connection with a given community or household. Because of the evidence from the Book of Acts and the inscription from Aphrodisias, the scholarly discussion about the "Godfearers" has generally located them in the orbit of Jewish communities, even when scholars do not consider them to have been real members of these communities. ${ }^{18}$ But what light do these sources shed on the relationship between Judaizers and Jewish communities?

\subsection{Josephus' ambiguous testimony}

The case of Helena and Izates, king of Adiabene, who ultimately converted to Judaism, illustrates the fact that in Josephus, too, most cases of adoption of Jewish customs are individual. ${ }^{19}$ Helena and Izates independently come to live according

17 One could also mention the testimony of Cassius Dio (67.14.2) concerning the consul Flavius Clemens and his wife, Flavia Domitilla, who under Domitian were accused of atheism, "a charge on which many others who drifted into Jewish ways were condemned." For Louis Feldman, they were Judaizers because as consul, Flavius Clemens could not give up Roman cults altogether and become a full proselyte. See Feldman 1993, 347.

18 See for example Stebnicka 2015. She talks about "pagans connected to the synagogue" (101).

19 The Judaization of the Idumeans from John Hyrcanus onward appears as an exception rather than a rule. 
to the Jewish laws after having been in touch with a Jew (anonymous in the case of Helena; a man called Ananias in the case of Izates). At no point does Josephus state that they were in touch with a local Jewish community in Adiabene. ${ }^{20}$ Ananias is a merchant and his encounter with Izates takes place outside Adiabene (Jewish Antiquities [Ant.] 20.34-36). Later on, Helena travels to Jerusalem, and has a palace and a funerary monument built there. Moreover, some of the descendants of Izates participate in the Judean war against Rome, which shows that the royal house of Adiabene had built a strong relationship with Judea. Still, the adoption of Jewish customs originally happened independently of a connection with a Jewish community.

Interestingly, in Ant. 14.110 Josephus mentions the wealth of the Jerusalem Temple and explains that it was due to the numerous offerings sent by Jews throughout the inhabited world and "those who worship God (tōn sebomenōn ton theon)", from Asia and from Europe. In this case, the phrase "those who worship God" probably refers to non-Jews who showed devotion toward the God of the Jews, rather than merely kings who made offerings to the Temple. The fact that these non-Jews sent contributions to the Jerusalem Temple could imply that they were in some way associated (or at least in touch) with a Jewish community. Unfortunately, we cannot deduce anything further from this passing reference.

A passage of Josephus' Judean War sheds a more interesting light on the issue of the participation of non-Jews in Jewish communities. Josephus reports that, before the war in Judea, the Jewish community in Antioch was numerous and enjoyed a prominent place in the city, so that "they (the Jews) were constantly attracting to their religious ceremonies (tais thrēskeiais) multitudes of Greeks, and these they had in some measure incorporated with themselves (kakeinous tropō tini moiran autōn pepoiēnto)" (J.W. 7.45; trans. H. St. J. Thackeray, LCL, 519). The Antiochean Jews had "somehow" (tropō tini) made these Judaizing Greeks, who participated in Jewish rituals, "a part of themselves" (moiran autōn). If Josephus is to be trusted, we have here a clear example of non-Jews who participated in Jewish religious practices within a community framework, and whom Josephus does not describe as converts but rather as Judaizers. ${ }^{21}$ This example, however,

20 Michał Marciak considers that there must have been Jewish communities in Adiabene. This makes sense, but the fact remains that Josephus never mentions that the royal house of Adiabene was in touch with Jewish communities there. See Marciak 2014.

21 See Schwartz 2007, 98, for a similar conclusion. 
remains quite exceptional in Josephus' work. ${ }^{22}$ And unfortunately (again), Josephus is vague regarding the exact way these non-Jews were considered part of the Jewish community. As a consequence, we cannot understand the details of this integration, nor answer questions such as whether they participated in the Jewish feasts, celebrated the Sabbath, joined the communal prayer, contributed to the money sent to Jerusalem for the sacrifices, etc. Yet, the idea that these Greeks had become part of the Jews implies that they were probably taking part in different festivals and community celebrations.

\subsection{Judaizers in synagogues in the Book of Acts?}

The Book of Acts is known for its numerous references to people who are not Jews, but show piety toward the God of Israel. When Paul visits Jewish communities in the Diaspora, he is said to encounter "proselytes" and "Godfearers" who participate in synagogal gatherings. At Antioch in Pisidia, on a Sabbath, Paul addresses the people in the synagogue in the following terms: "You Israelites [or: Israelite men], and those who fear God (kai hoi phoboumenoi ton theon), listen. The God of this people Israel chose our ancestors and made the people great during their stay in the land of Egypt ..." (Acts 13:16-17). Later in his speech, Paul again addresses the crowd in these terms: "My brothers, you descendants of Abraham's lineage, and those among you who fear God (kai hoi en humin phoboumenoi ton theon), to us the message of this salvation has been sent" (Acts 13:26). After Paul finishes his speech, the author adds this comment: "When the meeting of the synagogue broke up, many of the Jews and the devout (or [God-] fearing) proselytes (polloi tōn Ioudaiōn kai tōn sebomenōn prosēlutōn) followed Paul and Barnabas, who spoke to them and urged them to continue in the grace of God" (Acts 13:43). It is quite clear that, in the context of this passage, the "devout proselytes" (sebomenoi prosēlutoi) mentioned at the end are the people "who fear God" mentioned at the beginning of Paul's discourse, the second category of people attending the synagogal gathering. In accordance with most occurrences of the term prosēlutoi in the Septuagint, the "proselytes" are certainly converts, who have fully joined the Jewish community, but are distinguished from the native Jews, those who are "descendants of Abraham's lineage," by their genealogy, their foreign origins. As a consequence, this passage cannot be

22 Josephus also mentions that the wives of the inhabitants of Damascus had gone over to the Jewish cult (tē Ioudaikē thrēskeia), but it is unclear how these women were related to the Jewish community. See J.W. 2.559-561. 
used to demonstrate the existence of "Godfearers" alongside the proselytes, nor - obviously - the participation of the former in the life of the Jewish community. What we find in Acts 13 is a community composed of native Jews (Ioudaioi or Israēlitai) and proselytes, who are also described as devout.

We are then told that, as Paul's teaching was being received favorably by the non-Jews in the city, the Jews "incited the devout women of high standing (tas sebomenas gunaikas tas euschèmonas) and the leading men of the city, and stirred up persecution against Paul and Barnabas, and drove them out of their region" (Acts 13:50). This reference to "devout women," who may have been the wives of the "leading men of the city," recalls Josephus' passages on Judaizing women among the Roman aristocracy or in the cities of Syria. In Acts 13:50, the "devout women", who are not called "proselytes", may have been converts or may simply have been attracted to Jewish beliefs and rituals. The extent of their adoption of Jewish practices remains unclear, as does the nature of their relationship with the Jewish community. ${ }^{23}$

In the next chapter, Paul and Barnabas reach Iconium and again address the people at the local synagogue. The author briefly states that they "spoke in such a way that a great number of both Jews and Greeks (Ioudaiōn te kai Hellēnōn polu plēthos) became believers" (Acts 14:1). In verse 2 these Greeks are described as ta ethne, a term the Septuagint and Jewish works written in Greek use to designate the nations, the non-Jews. This passage therefore seems to allude to the presence of non-Jews who were not converts at a synagogal meeting (whether it took place on the Sabbath is not specified).

Again, in Beroea, Paul preaches to the Jews in the synagogue, and we are told that "many of them therefore believed, including not a few Greek women and men of high standing" (Acts 17:12). These Greek women are not presented as "devout" as in Acts 13, but their presence in the synagogue testifies to their participation in the life of the community in one way or another. The question that arises is whether they were married to Jewish men, or should be considered "Judaizers" from outside the community.

Finally, we read that in Athens, Paul "argued in the synagogue with the Jews and the devout (or [God-]fearing) ones (kai tois sebomenois), and also in the marketplace every day with those who happened to be there" (Acts 17:17). Contrary to Acts 13, nothing in this passage helps clarify whether these Godfearing persons were proselytes (that is, converts) or non-Jews participating in

23 Acts 16:14 mentions another woman who was "fearing God," Lydia, a dealer in purple cloth from Thyatira. However, the encounter between Lydia and the apostles takes place outside the city of Philippi, near a river, and it is unclear whether this place was a spot where the Jewish community gathered. 
a synagogal meeting out of piety toward the God of the Jews, or both, and to what extent the latter adopted Jewish customs.

Ultimately, the evidence from the Book of Acts does not really clarify to what extent and in what ways Judaizers were connected to Jewish communities. If its testimony is historically reliable, it documents the presence of proselytes (i.e. converts) in some communities, as well as the presence of non-Jews (not described as proselytes) attending synagogal gatherings, in such places as Iconium or Beroea. That the latter were also practicing Jewish rituals is indeed possible, but not certain. In any case, the details elude us, as well as the nature of the relationship: did they participate regularly or occasionally in Jewish celebrations? Was this participation passive or active? Were they taught to practice certain things but forbidden to adopt other types of practices? Were these non-Jews supposed to convert after a time? Most of our questions remain unanswered.

\subsection{The synagogue "of the Jews and the Godfearers" in Pantikapaion}

An inscription from the region of the Bosporan kingdom, dated to the 1st century CE - roughly the same period as Josephus and the Book of Acts -, pertains to the manumission of a slave in the context of a proseuche, under the supervision of "the community of the Jews and the Godfearers" (tēs sunagō- / gēs tōn Ioudaiōn kai theon / sebōn [probably to be corrected to theon sebomenōn], Corpus Inscriptionum Regni Bosporani [CIRB] 71, lines 8-10; alternative reading: theo $<n>$ sebōn). Elizabeth Leigh Gibson translates the inscription as follows: “. . . I release in the prayerhouse my slave Elpis in order that she is undisturbed and unassailable by any heir, except for service to the prayerhouse (proseuchē), as a guardian, the synagogue of the Jews and the godfearers." 24 This means that the community of the Jews and Godfearers is in charge of supervising the implementation of the manumission act. In similar inscriptions from Pantikapaion such as CIRB 70 and 72, reference is made only to "the community of the Jews," without any mention of the Godfearers. Some scholars have suggested understanding theon sebōn as referring to the slave who is manumitted, who should commit to continuing to worship the deity. ${ }^{25}$

24 Leigh Gibson 1999, 161; she follows the interpretation of Bellen (1965-66). Greek text taken from Lifschitz 1975, 173.

25 This is the suggestion made by the editors of Inscriptiones Judaicae Orientis. Vol. 1: Eastern Europe, David Noy, Alexander Panayatov and Hanswulf Bloedhorn. See Inscriptiones Judaicae Orientis (IJO) 1:282-283. 
However, the syntax would be very difficult. Bellen and Leigh Gibson are thus probably right that we are dealing here with a community composed of both (native) Jews and Godfearers. ${ }^{26}$ Whether these Godfearers were proselytes, as in Acts 13, or non-Jews who worshiped the God of Israel with the Jews without undergoing a formal conversion (which may not yet have been codified in this Bosporan context), we simply do not know. However, the fact that they were jointly responsible for the implementation of the manumission acts does indicate that their implication in the community was deep and long-lasting.

\subsection{The Case of the Theosebeis in Aphrodisias}

A tall marble block discovered in Aphrodisias provides us with an inscription documenting the life of a Jewish community in the city, probably during the 4th century CE. According to the original editors, Joyce Reynolds and Robert Tannenbaum, the inscription - which mainly consists of lists of names and was carved on adjoining faces of the marble block - runs from face a to face b (Reynolds and Tannenbaum 1987). This conclusion has been challenged by Angelos Chaniotis, who considers that we are dealing with two separate inscriptions (Chaniotis 2002). He notes that the one engraved on side b, which he calls face I and considers the oldest one, is more clearly written and more properly arranged on the stone. The inscription on side a, which Chaniotis calls face II, was added later, after the stone had already been erected, making the engraving work more difficult. As a consequence, the lists on side b (face I) should not be read as a continuation of the list on side a (face II). Chaniotis argues that the beginning of the list on side b (face I) is now lost because the stone is damaged, which prevents us from understanding the circumstances that led to the erection of this commemorative stele.

First, let us look at the inscription(s) according to the interpretation proposed by Reynolds and Tannenbaum, keeping in mind that even if the inscriptions were engraved successively, they nevertheless both probably date from the 4th century $\mathrm{CE}^{27}$ One side of the stone (side a in the edition of Joyce Reynolds and Robert

26 Irina Levinskaya mentioned to me in a private conversation that an unpublished manumission inscription from the Bosphorus area, dated to the beginning of the 2nd century CE, refers to "the synagogue of the Ioudaioi and the theosebeis". I look forward to the publication of this document.

27 Its first editors, Joyce Reynolds and Robert Tannenbaum, dated the inscription to the beginning of the 3rd century CE, whereas Angelos Chaniotis dates it to the 5th century CE. The arguments later put forward by Gilbert Gary in favor of a 4th century dating - not excluded by Chaniotis himself - seem decisive to me (Gary 2004). 
Tannenbaum, face II in Chaniotis' interpretation) mentions the activity of a group calling itself the dekania, which aims to provide relief from affliction (apenthēsia) for the plethos, identified either as the Jewish community or as the people of Aphrodisias (this second possibility seems to me less likely). ${ }^{28}$ The dekania is defined as "the decany of those who love to learn, (also known as) those who fervently praise (God) (or: those who worship [God] constantly)," and who are also responsible for the memorial. The inscription then records a list of donors, or, more precisely, two lists separated by a vacat, if one follows the interpretation of Reynolds and Tannenbaum. The first one names 19 individuals on side a and 56 individuals on side $b$, most of whom are apparently Jewish, according to their names, which are sometimes followed by their patronymic, or a title (such as presbeutēs, elder), or an indication of profession. On side $b$, after a vacat, we then have a second list of 50 individuals, which is introduced by the words kai hosoi theosebis (to be read theosebeis), "and those who are Godfearers." This second list first mentions the names of nine bouleutai, or elected members of the city council, and then various additional names with their patronymic, or a title, or an indication of profession. As Pieter van der Horst notes, it is remarkable that this list contains the names of nine city councilors, and "as a matter of fact we can see that the jobs done by the Godfearers, of which some 22 are given in the inscription, cover a wide range of occupations only very few of which indicate lower social status" (Van der Horst 2015, 39). That these theosebeis are not proselytes is made clear by the fact that in the first list (on side a, lines 13, 17 and 22), three proselytes (prosēlutoi) are explicitly mentioned. However, the first list (side a, lines 19 and 20) also contains the names of two theosebeis, Emmonios and Antoninos, mixed together with the other names. If the two sides of the stone are to be read as a single inscription, as argued by Reynolds and Tannenbaum, then we are left wondering why two persons explicitly characterized as theosebeis feature in the first list, whereas another group of persons is presented as theosebeis separately.

If, however, we follow Chaniotis' analysis of the stone, side $a$ and side $b$ have to be interpreted separately, and in this context the fact that theosebeis are mentioned on both sides of the stone is no longer problematic. We then have a list of donors to a charitable organization of some sort, on the one hand (side a), and probably another list of benefactors divided into two categories - Jews and

28 For the second interpretation of plēthos, see Gary 2004, 170 n. 3. According to Reynolds and Tannenbaum, the service provided by the dekania was a sort of soup kitchen for the needy. Others have suggested that it was a burial society. See in particular Williams 1992, 307. 
non-Jews - on the other hand (side b). That non-Jews acted as benefactors towards Jewish communities is well attested in other literary and epigraphical sources. ${ }^{29}$ It is quite clear that this attitude was seen as a mark of piety by the Jews, and probably by the donors themselves (even if other issues were at stake in their euergetism). The list of theosebeis on side $b$, starting with the names of nine bouleutai of the city, should thus certainly be interpreted as a list of nonJewish benefactors. It may be compared with an inscription commemorating the donation made to a synagogue in Acmonia (in Phrygia) by a non-Jewish woman named Julia Severa, who served as priestess of the imperial cult, and whose eunoia and spoude the inscription celebrates (Inscriptiones Judaicae Orientis [IJO] 2: 348-355, no. 168). Or it may be compared to another inscription commemorating a woman named Capitolina, who made a donation to a religious building and is described as theosebēs, and who may have been the wife of a Roman senator and priest for life of Zeus Larasios in Tralles (in Caria) (IJO 2:140-143, no. 27). However, as Ross Shepard Kraemer emphasizes,

even if this inscription commemorates donations to a synagogue by a non-Jewish woman benefactor, whether it testifies to a specific attachment to Jewish practice, alluded to, if not indicated by the term theosebes, cannot be determined. It might simply indicate that gifts to a Jewish synagogue could be construed as a general form of piety (remembering that for Gentiles, the Jewish god was still a god).

(Kraemer 2014, 77)

Similar caution should be taken in the case of the theosebeis on side b of the inscription from Aphrodisias. Whether these benefactors venerated the God of the Jews to the point of adopting certain Jewish practices remains hypothetical. ${ }^{30}$ Moreover, there is in fact no reason to suppose that all these individuals necessarily had similar ideas and practices.

29 In Acts 10:2, we are told that the centurion Cornelius "was a pious man who feared God (eusebēs kai phoboumenos ton theon) with all his household; he gave alms generously to the people and prayed constantly to God" (NRSV, slightly modified). Here we have a case (no matter how fictional it may be) that combines veneration and prayer to the God of Israel with euergetism or charity. Luke 7:5 also records a Roman centurion in Capernaum who was benevolent toward the Jews and had a synagogue built there; he is not described as theosebees, but implicitly as pious, and later on Jesus himself praises him for his exceptional faith. See Van der Horst 2015, 31-32; Kraemer 2014, 73-79. However, in the synagogue of Sardis, the inscriptions that mention theosebeis - 6 out of a total of approximately 80 - refer to pious Jews, according to Marianne Palmer Bonz (1994). For Ross S. Kraemer, the theosebeis from Sardis may have been pious Jews, or pious non-Jews who merely donated to the synagogue, or Judaizers (Kraemer 2014, 74). The inscriptions from Sardis date from the 4th to 6th century CE. See IJO 2.67; 2.68; 2.83; 2.123; 2.125; 2.132 (also catalogued as I. Sardis 8, 9, 22, 57, 59, 66).

30 For a similar conclusion, see Kraemer 2014, 80-81. 
The case of the two theosebeis (Emmonios and Antoninos) mentioned on side $\mathrm{a}$ in the list of members of the dekania is different. Marianne Palmer Bonz has argued that we are dealing here with two pious Jews, rather than with "Godfearers" in the sense of pious non-Jews somehow related to a Jewish community (Palmer Bonz 1994, 292-293). This interpretation, however, is not likely, because nearly all the other names in this list are followed by a patronym, a title or a profession. ${ }^{31}$ In my opinion, in this context theosebēs is a title indicating a particular status, like prosēlutos. What is remarkable is that in this particular instance, we know for certain that these two theosebeis were part of the Jewish community, or at least part of the group known as the dekania. ${ }^{32}$ The beginning of the inscription states very clearly that the names listed on the stone are those of "the members of the decany of those who love to learn, (also known as) those who fervently praise (God)" (lines 2-5). Emmonios and Antoninos, the godfearers, were thus part of a group involved in study (probably of Jewish sacred texts) and worship (probably of the Jewish God) together with those who were apparently native Jews (Yael, Joshua, Samuel, etc.) and several proselytes (Samuel, Joses, Joseph). The fact that Samuel the proselyte was president of the dekania shows that proselytes were not considered inferior in rank compared to native Jews, and may help explain the openness of the dekania to non-Jews who were willing to learn and worship with the Jews.

All in all, then, the literary and epigraphic sources document Judaizers (non-Jews involved in the practice of Jewish customs or rituals) and individuals generally described as Godfearers who are closely associated with Jewish communities: they may contribute financially to the community buildings or charity associations, act as witnesses and guarantors in manumissions performed in a proseuche, and even participate in religious activities such as prayers or the study of sacred books. Not all these activities can be characterized as "Judaizing" acts. Financial contributions, material or even political support could stem from individuals who acted as euergetes or aimed to behave piously toward all the gods,

31 The only exception is Ioudas eukolos on line 16, "Judas the good-tempered," which sounds like a nick-name (if we consider for instance Menander's duskolos).

32 In Inscriptiones Judaicae Orientis II, Walter Ameling writes that „Die Aphrodisias-Inschrift macht klar, daß die theosebeis von den Juden als Teil ihrer Gemeinde betrachtet wurden - wie locker die Verbindung in den Augen der theosebeis auch gewesen sein mag“ (Ameling 2004, 18). On p. 18 he also quotes with approval the English revised edition of Schürer 1973-1987, III/1, 166: "It would be difficult to imagine clearer evidence that theosebeis could be categorized as a formal group attached to a Jewish community, and distinguished both from Jews and from full proselytes." The problem is that these scholars do not make a distinction between the theosebeis on side b, who were probably not part of the Jewish community, and the theosebeis on side a. 
including the god of the Jews, but without adopting Jewish customs or beliefs. In certain cases, however, the use of the term theosebess is associated with Judaizing practices such as prayers or study - attention should be paid to the fact that in the case of the godfearers Emmonios and Antoninos, Judaizing practices are clearly attested, whereas the verb ioudaizein is not used, which again shows that we face a great deal of terminological flexibility in the ancient sources.

Contrary to the picture that emerged from the Latin literary sources, the Judaizing practices alluded to in the inscription from Aphrodisias seem to have taken place in a community setting, a point which the testimonies of Josephus and the Book of Acts confirm only in part. If we take all the evidence into account, a good case can be made for connecting the Judaizers with Jewish communities in certain contexts, but we cannot exclude that Judaizers occasionally developed individual or household practices, without participating in the cultic life of a Jewish community.

\section{The rabbis' attitude toward the Judaizers}

Philo and Josephus both referred to Judaizers with pride, as proof of the superiority or the rationality of Jewish Law. Such statements were coherent with the apologetic perspective of their works. But let us now look at the phenomenon of the Judaizers from a different (though still Jewish) perspective, that of the rabbis. Rabbinic texts occasionally refer to "Heaven-fearers" (yirey shamayim), whom most scholars identify as pious non-Jews who worshiped the God of Israel and imitated Jewish practices, but without undergoing full conversion. ${ }^{33}$ Moreover, most scholars consider that the rabbis viewed these Judaizing gentiles - often described as "sympathizers" - in a positive light.

The issue is quite intricate. First, there are very few references to yirey shamayim in rabbinic literature from the Land of Israel up to the 5th century CE no more than a dozen. ${ }^{34}$ As far as the Babylonian Talmud is concerned, nearly all the occurrences of yirey shamayim refer to pious Jews, not to Judaizers (Feldman 1993, 353).

Second, the meaning of the expression yirey shamayim varies from text to text. Just as Jews or Greeks or Romans can be theosebeis, in rabbinic literature

33 See Lévi, 1905-1907; Lieberman 1994, 68-90; Siegert 1973, 110-119; Feldman 1993, 353-356; Levinson 2000.

34 For the sake of comparison, in the same corpus there are around five hundred occurrences of the term ger, "proselyte". 
Jews can be yirey shamayim too, and in this case the phrase refers to Jewish devotion toward the God of Israel. ${ }^{35}$ In some cases the expression could also refer to converts. This is at least the way Numbers Rabbah 8:2 (a late midrash or biblical commentary) interprets an earlier midrashic passage, Mekhilta deRabbi Ishmael Nezikin 18, which mentions both converts and Heaven-fearers.

Third, even when the yirey shamayim are not to be identified with Jews or converts, in most cases the fact that individuals are designated as such does not allow us to determine what kind of Jewish practices they adopted. ${ }^{36}$ In some cases, it looks as though yirey shamayim could also be gentiles who protected Jews, or merely expressed admiration for the God of Israel. However, one tradition, found in three parallel passages of the Jerusalem Talmud, evokes Heaven-fearers wearing broken sandals (a sign of mortification) on the Day of Atonement. ${ }^{37}$ These texts can be compared to Philo's and Josephus' testimony concerning the non-Jews who fast on the Day of Atonement. But this is almost everything we are told about the Judaizing practices of these Heaven-fearers.

Finally, an important aspect of the rabbinic traditions concerning the Heaven-fearers, to which no attention has yet been paid, is that these traditions feature in haggadic texts and not in halakhic ones. Halakhic texts represent the core of rabbinic Judaism, because they deal with the Law and the way Jews should practice the divine commandments. By contrast, haggadic texts include anecdotes, theological or eschatological speculations, legends, ethical discussions, etc. Even if a few haggadic passages refer positively to gentiles who were devout toward the God of Israel, this does not imply that the rabbis viewed non-Jews who imitated Jewish practices with favor. A closer look at the rabbinic evidence in fact shows that the contrary is true.

First, the yirey shamayim are absent from the halakhic texts that discuss the different groups constituting Israel (priests, Levites, Israelites, converts, freed slaves, etc.), which means that yirey shamayim were not part of Israel. Second, several halakhic texts define what the path of righteous non-Jews should be: they should observe the seven commandments of the descendants of Noah, which include the rejection of idolatry and blasphemy, the necessity of establishing courts of justice, the condemnation of murder, theft, illicit sexual relations, and cruelty towards animals (Tosefta Avodah Zarah 9:4; see Novak 2011). These commandments do not include any specific Jewish custom, such as the Sabbath, the fast of Kippur, abstinence from eating certain food, etc. In fact, the rabbis came to see the

35 See for example Genesis Rabbah 49:2 and Leviticus Rabbah 12:2.

36 See for example Genesis Rabbah 28:5 and Leviticus Rabbah 3:2.

37 See Jerusalem Talmud, Megillah 1:10 (72b); Megillah 3:1 (74a); Sanhedrin 10:3 (29c). 
commandments of the Torah (the Law revealed by God) as the exclusive property of Israel and those who underwent a full conversion "for the sake of Heaven". Non-Jews who did not convert - who did not become Jews - were forbidden from observing Jewish customs. Hence, a passage from the Babylonian Talmud (Sanhedrin 58b) attributed to the 3rd century Rabbi Simeon ben Lakish, teaches that a non-Jew who rests on the Sabbath deserves death (see Feldman 1993, 356).

From the rabbinic perspective, which differs greatly from that of Philo or Josephus, Jewish monotheistic beliefs may be shared by non-Jews, who will be praised for their belief, and are expected to renounce idolatry if they are to be considered righteous, but it is impossible for the commandments (mitzvot) of the Torah to be shared with non-Jews or observed by non-Jews who do not convert. Even if dissenting voices can be heard in rabbinic texts, on the whole, rabbinic Judaism is tantamount to a deep rejection of the appropriation of Jewish rituals and customs by non-Jews, as opposed to the appropriation of Jewish beliefs.

This, however, does not mean that the rabbis were able to stop non-Jews from practicing Jewish rituals or participating in synagogal gatherings. As Seth Schwartz and Hayim Lapin have shown, the rabbinization of the Jewish world was slow, and may not even have been fully completed until the Middle Ages, if ever (see Schwartz 2001; Lapin 2012). Moreover, numerous cases of Judaizing Christians or non-Jews more generally, even up to modern times, show that the phenomenon is an enduring one.

\section{Conclusion}

The literary and epigraphic sources examined in this paper pose numerous problems of interpretation. However, the cumulative evidence nevertheless shows that non-Jewish individuals did in fact adopt Jewish beliefs, customs and rituals without undergoing conversion, strictly speaking. What is most prominent is the observance of the Sabbath, the practice of fasting (either on the Sabbath or at certain festivals like the Day of Atonement), giving up certain foods such as pork (these practices are mentioned mainly in literary sources), participation in synagogal gatherings, prayer, and even the study of sacred texts (in the case of the dekania of Aphrodisias). Judaizers did sometimes send financial contributions to Jewish communities or the Jerusalem temple (before $70 \mathrm{CE}$ ), but such gifts could also be sent by pious or benevolent non-Jews who did not engage in Judaizing practices; therefore this behavior is not really helpful to identify Judaizers. The latter were not necessarily connected to a Jewish community, but there are hints that some were, even if we do not know the exact nature of the relations between these Judaizers and the Jewish communities, and even though these relations probably varied 
greatly from place to place and over time. Whereas some inscriptions, such as those from Pantikapaion and Aphrodisias, testify to such a connection, rabbinic writings, which allude only marginally to the existence of Judaizers, tend to forbid non-Jews from practicing specifically Jewish rituals and customs, while encouraging them to adopt Jewish monotheistic beliefs and to give up idolatry. In contrast with the writings of Philo and Josephus and epigraphic testimony, rabbinic literature develops a normative discourse on Jewish religious practices that tends to control, exclude and establish boundaries between those who partake in the Sinaitic covenant and those who do not.

\section{Bibliography}

Ameling, Walter 2004. Inscriptiones Judaicae Orientis. Band II, Kleinasien. Tübingen. Barclay, John M. G. 2007. Flavius Josephus. Against Apion: Translation and Commentary. Leiden.

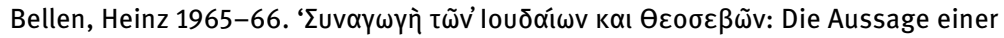
bosporanischen Freilassungsinschrift (CIRB 71) zum Problem der “Gottesfürchtigen”, Jahrbuch für Antike und Christentum 8/9. 171-176.

Chaniotis, Angelos 2002. 'The Jews of Aphrodisias: New Evidence and Old Problems', Scripta Classica Israelica 21. 209-242.

Cohen, Shaye J. D. 1987. 'Respect for Judaism by Gentiles according to Josephus', Harvard Theological Review 80. 409-430.

Cohen, Shaye J. D. 1989. 'Crossing the Boundary and Becoming a Jew', Harvard Theological Review 82. 13-33.

Cohen, Shaye J. D. 1999. The Beginnings of Jewishness: Boundaries, Varieties, Uncertainties. Berkeley.

Feldman, Louis H. 1950. 'Jewish "Sympathizers”: Classical Literature and Inscriptions', Transactions and Proceedings of the American Philological Association 81. 200-208.

Feldman, Louis H. 1993. Jew and Gentile in the Ancient World: Attitudes and Interactions from Alexander to Justinian. Princeton.

Fredriksen, Paula 2015. "“If It Looks like a Duck, and It Quacks like a Duck ...”: On Not Giving Up the Godfearers.' In A Most Reliable Witness: Essays in Honor of Ross Shepard Kraemer, ed. Susan Ashbrook Harvey et al. Providence. 25-33.

Gary, Gilbert 2004. 'Jews in Imperial Administration and Its Significance for Dating the Jewish Donor Inscription from Aphrodisias', Journal for the Study of Judaism 35. 169-184.

Goldenberg, Robert 1979. 'The Jewish Sabbath in the Roman World up to the Time of Constantine the Great', ANRW II.19.1. 414-447.

Hezser, Catherine 2005. Jewish Slavery in Antiquity. Oxford.

Horbury, William 1991. 'Herod's Temple and Herod's Days.' In Templum Amicitiae: Essays on the Second Temple Presented to Ernst Bammel, ed. William Horbury. London. 103-149.

Kraemer, Ross S. 2014. 'Giving up the Godfearers', Journal of Ancient Judaism 5. 61-87. Lapin, Hayim 2012. Rabbis as Romans: The Rabbinic Movement in Palestine, 100-400 C.E. Oxford. Leigh Gibson, Elizabeth 1999. The Jewish Manumission Inscriptions of the Bosporus Kingdom. Tübingen. 
Levinskaya, Irina 1996. The Book of Acts in Its Diaspora Setting. Grand Rapids.

Levinson, Joshua 2000. 'Bodies and Bo(a)rders: Emerging Fictions of Identity in Late Antiquity', Harvard Theological Review 93/4. 343-372.

Lévy, Israël 1905-1907. 'Le prosélytisme juif', Revue des Études Juives 50: 1-9; 51: 1-31; 53: 56-61.

Lieberman, Saul 1994. Greek in Jewish Palestine. New York.

Lieu, Judith M. 1995. 'The Race of the God-Fearers', Journal of Theological Studies 46. 483-501.

Lifschitz, Baruch 1975. 'Prolegomenon.' In Corpus Inscriptionum Iudaicarum. Vol. 1, Europe, ed. Jean-Baptiste Frey. New York.

Marciak, Michat 2014. Izates, Helena, and Monobazos of Adiabene: A Study on Literary Traditions and History. Wiesbaden.

Novak, David 2011. The Image of the Non-Jew in Judaism: The Idea of Noahide Law. Portland.

Noy, David; Panayatov, Alexander; Bloedhorn, Hanswulf 2004. Inscriptiones Judaicae Orientis. Vol. 1: Eastern Europe. Tübingen.

Palmer Bonz, Marianne 1994. 'The Jewish Donor Inscriptions from Aphrodisias: Are They Both Third-Century, and Who Are the Theosebeis?' Harvard Studies in Classical Philology 96. 281-299.

Reinach, Théodore 1894. Textes d'auteurs grecs et romains relatifs au judaïsme. Paris.

Reynolds, Joyce; Tannenbaum, Robert 1987. Jews and Godfearers at Aphrodisias. Cambridge.

Robert, Louis 1937. Études anatoliennes. Paris.

Schürer, Emil 1973-1987. The History of the Jewish People in the Age of Jesus Christ (175 B.C.-A.D. 135), rev. and enl. by Geza Vermes, Fergus Millar, Matthew Black. Edinburgh.

Schwartz, Daniel R. 2007. 'Doing like Jews or Becoming a Jew? Josephus on Women Converts to Judaism.' In Jewish Identity in the Greco-Roman World, ed. Jörg Frey, Daniel R. Schwartz, Stephanie Gripentrog. Leiden. 93-109.

Schwartz, Seth 2001. Imperialism and Jewish Society, 200 B.C.E. to 640 C.E. Princeton.

Schwartz, Seth 2011. 'How Many Judaisms Were There? A Critique of Neusner and Smith on Definition and Mason and Boyarin on Categorization', Journal of Ancient Judaism 2/2. 208-238.

Siegert, Folker 1973. 'Gottesfürchtige und Sympathisanten', Journal for the Study of Judaism 4. 107-164.

Stebnicka, Krystyna 2015. Identity of the Diaspora: Jews in Asia Minor in the Imperial Period. Warshaw.

Stern, Menahem 1974-1984. Greek and Latin Authors on Jews and Judaism. Jerusalem.

Van der Horst, Pieter W. 1991. Ancient Jewish Epitaphs: An Introductory Survey of a Millennium of Jewish Funerary Epigraphy (300 BCE - 700 CE). Kampen.

Van der Horst, Pieter W. 2015. Saxa Iudaica Loquuntur: Lessons from Early Jewish Inscriptions. Leiden.

Wander, Bernd 1998. Gottesfürchtige und Sympathisanten: Studien zum heidnischen Umfeld von Diasporasynagogen. Tübingen.

Williams, Margaret 1992. 'The Jews and Godfearers Inscription from Aphrodisias: A Case of Patriarchal Interference in Early 3rd Century Caria?', Historia 41/3. 297-310.

Williams, Margaret 2004. 'Being a Jew in Rome: Sabbath Fasting as an Expression of RomanoJewish Identity.' In Negotiating Diaspora: Jewish Strategies in the Roman Empire, ed. John M. G. Barclay. London. 8-18. 
